\title{
CHARLES HADDON SPURGEON: WHAT CAN WE LEARN FROM HIM FOR TODAY?
}

\author{
Andrew McGowan \\ University of the Highlands \\ Correspondence: Andrew.McGowan@uhi.ac.uk
}

\begin{abstract}
In this article, the author gives an account of the life and theology of C.H. Spurgeon (1834-1892). The account demonstrates that Spurgeon was not only the most renowned preacher of his day, most of whose sermons were published and are still read widely today but also an author who published many volumes. In addition to his work as preacher and writer, Spurgeon built children's orphanages, started a theological college and assisted in many noble causes. As part of this benevolent work, his church contributed large sums to support poor relief. Having told Spurgeon's story, the article then indicates six areas of Spurgeon's life and ministry which are helpful for us today: (1) his passion for souls; (2) his devotion to prayer and study; (3) his attitude to the Bible \& expository ministry; (4) his pastoral ministry; (5) his practical christianity; and (6) his refusal to compromise on the truth of the gospel.
\end{abstract}

KEYWORDS: Spurgeon, ministry, preach, Bible

ABSTRAK: Dalam artikel ini, penulis memberikan catatan tentang kehidupan dan teologi C.H. Spurgeon (1834-1892). Catatan ini menunjukkan bahwa Spurgeon bukan hanya pengkhotbah paling terkenal pada zamannya, sebagian besar khotbahnya diterbitkan dan masih dibaca secara luas hingga hari ini, tetapi juga seorang penulis yang menerbitkan banyak karya. Selain pekerjaannya sebagai pengkhotbah dan penulis, Spurgeon membangun panti asuhan anak-anak, memulai sebuah perguruan tinggi teologi dan membantu banyak dalam pekerjaan yang mulia. Sebagai bagian dari pekerjaan penuh belas kasih ini, gerejanya menyumbangkan banyak uang untuk bantuan kemiskinan. Setelah kisah Spurgeon, artikel ini menunjukkan enam bidang kehidupan dan pelayanannya yang bermanfaat bagi kita dewasa ini: 
(1) hasratnya terhadap jiwa; (2) semangatnya untuk berdoa dan belajar; (3) sikapnya terhadap pelayanan Alkitab \& ekspositori; (4) pelayanan pastoralnya; (5) kekristenan praktisnya; dan (6) penolakannya untuk berkompromi tentang kebenaran Injil.

KATA KUNCI: Spurgeon, pelayanan, khotbah, Alkitab

\section{Introduction}

Across the road from my office is the Dingwall Free Church of Scotland building. I have preached there on a number of occasions and I remember the first occasion, when I was shown into the high pulpit and told that C.H. Spurgeon, the famous London preacher of the nineteenth century, had preached from that very pulpit. Spurgeon had been a great friend of the minister of the church, Dr John Kennedy, ${ }^{1}$ who was himself regarded by many as one of the greatest Highland ministers of the 19th Century. ${ }^{2}$ Iain Murray described him as 'one of the greatest evangelists Scotland has ever raised'. ${ }^{3}$ Indeed, when Kennedy died, Spurgeon wrote of him to his widow as one 'whom I venerated as every inch a man of God. His death was a loss to the Highlands greater than could have befallen by the death of any other hundred men'. ${ }^{4}$

When I see the church across the road, then, I often think of Spurgeon and have come to believe that there is a great deal we can learn from this man. C.H. Spurgeon was probably the most famous preacher of the 19th century and he is still today widely read and quoted. ${ }^{5}$

\section{Biography}

What was it, then, about this man which would make people want to remember him? In order to answer that question, let us consider what we can learn from Spurgeon for today. We begin by considering some biographical

\footnotetext{
1 For the story of Kennedy's life, see Alexander Auld, Life of John Kennedy DD (London: T. Nelson \& Sons, 1887).

2 Kennedy was a famous preacher but also an author. See John Kennedy, The Days of the Fathers in Ross-shire (Inverness: Christian Focus Publications, 1979), originally published in 1861; John Kennedy, The Apostle of the North (London: T. Nelson \& Sons, 1866). He also wrote a booklet on hyper-evangelism, criticising the evangelistic methods of D.L. Moody, available at: https://www.monergism.com/ hyper-evangelism-another-gospel-though-mighty-power

3 Iain Murray, The Forgotten Spurgeon (London: Banner of Truth, 1966), 179.

4 Unpublished private letter, referred to in a database of material concerning Dr Kennedy: http:// www.nesherchristianresources.org/JBS/kennedy/Memoir_of_Dr_Kennedy.html

5 Many Christians use the popular Morning and Evening daily devotional written by Spurgeon and available widely in print and on-line.
} 
details. $^{6}$

Charles Haddon Spurgeon was born in 1834 in Essex. He came from a Christian family, and indeed both his father and grandfather were ministers. His parents moved to Colchester when he was just under a year old but things were hard for them at first and so Charles went to stay with his grandparents and his aunt in Stanbourne, another small village in Essex. ${ }^{7}$ He greatly enjoyed his time there and, under the influence of a godly home, began to read good Christian books like Bunyan's Pilgrim's Progress, ${ }^{8}$ and Baxter's Call to the Unconverted. ${ }^{9}$ Clearly these books 'were instrumental in the hands of the Spirit of God to create in Charles a sense of the need of salvation' ${ }^{10}$

At the age of six he returned to his parents' home in Colchester and, although he found it hard at first, soon settled. Even at this early stage some of the characteristics of the later Spurgeon began to show themselves. He had a strong and determined character, he was quick to learn, he loved to read, and he would persist in asking questions until he obtained a satisfactory answer. In the interim period, while he had been at Stanbourne, his parents had added to their family, and he now had a brother and two sisters. In fact, his mother gave birth to seventeen children altogether, nine of whom died in infancy.

He attended Stockwell School in Colchester until he was fourteen, when he went for one year to a Church of England school in Maidstone where his uncle was one of the teachers. ${ }^{11}$ Then in 1849 he went to Newmarket Academy where he was employed as an 'usher'. This meant that he acted as a tutor to some of the younger boys while still being taught himself. During the following winter he was back home for a considerable period in Colchester because of an outbreak of fever which had closed the school. Spurgeon had for some time been concerned about his spiritual condition,

6 Spurgeon's autobiography, originally published in four volumes between 1897-1900, is a primary source for understanding the man. It was republished in two volumes as C.H. Spurgeon Autobiography Vol.1: The Early Years, 1834-1859 and C.H. Spurgeon Autobiography Vol.2: The Full Harvest, 1860-1892 (Edinburgh: Banner of Truth, 1973). In addition to Murray's volume already mentioned, there are various other good bibliographical sources. The 'authorised' biography (Spurgeon read the proofs of all but the last chapter describing his final days) is R. Shindler, From the Usher's Desk to the Tabernacle Pulpit: The Life and Labours of Pastor C.H. Surgeon (London: Passmore and Alabaster, 1897). Some more modern biographies are: G. Holden Pike, The Life \& Work of Charles Hadden Spurgeon, two vols., (Edinburgh: Banner of Truth, 1991); Arnold Dallimore, Spurgeon: A New Biography (Edinburgh: Banner of Truth, 1985); Lewis A. Drummond, Spurgeon: Prince of Preachers (Grand Rapids: Kregel Publications, 1992); and Tom Nettles, Living by Revealed Truth: The Life and Pastoral Theology of Charles Haddon Spurgeon (Fearn: Mentor, 2013).

Spurgeon, Autobiography 1, 3-21.

John Bunyan, Pilgrim's Progress (London: Penguin Classics, 2008).

Richard Baxter, Call to the Unconverted (Grand Rapids: Zondervan, 1953).

10 Drummond, op cit, 104-105.

11 Holden Pike, op cit, 28-31. 
and during this enforced period at home he gave the matter great consideration. One of his decisions was to visit every church in the town in order to discover the way of salvation. The young Spurgeon 'visited many of the chapels in Colchester, trusting to hear a word of hope, but to no avail.'12

On Sunday 6th January 1850, he set out for a particular church in the town centre but a snowstorm made it impossible for him to get there, so instead he slipped into a Primitive Methodist Chapel. The minister of the church couldn't get there himself because of the snow and so the pulpit was taken by a member of the congregation. Spurgeon tells us that at first he was unimpressed. The man was a shoemaker or tailor and was not educated. In fact, he was barely able to do more than repeat the words of his text which was, 'Look unto me and be ye saved, all the ends of the earth'. Noticing Spurgeon, he addressed himself directly to the young man, and encouraged him to do what the text required, to look to God and be saved. ${ }^{13}$

At that moment Spurgeon became a Christian, his sins were forgiven, and he joyfully and enthusiastically entered upon the Christian life. He went back to Newmarket and gave more and more of his time to preaching and distributing tracts around the houses in the area, and he pleaded with his father to let him become a preacher of the gospel. Eventually he agreed but it was a little time before it came to pass.

He was baptised in May (although he did not join a Baptist church until some months later) and in August he moved to a new school in Cambridge. The school was run by a devout Christian and centred on the things of the faith. Spurgeon taught, and at the same time gave himself to the study of theology in preparation for what he knew would be his life's work. ${ }^{14}$

Before long he was preaching every Sunday and many times midweek to various small congregations within walking distance of Cambridge. Finally, in October 1851, at the age of 17, he became the pastor of a small Baptist church in the village of Waterbeach, a few miles from Cambridge. ${ }^{15}$ He had a remarkable ministry there, seeing many converted and the church doubled in size. He became known as the 'boy preacher of the Fens'. ${ }^{16}$

It was no surprise to his deacons (although it seemed to surprise Spurgeon) when, in 1853, a famous old Baptist church in London invited him to come and preach for them. This was New Park Street Church in Southwark. The building held around 1,200 but the congregation had come

\footnotetext{
Drummond, op cit, 114.

Nettles, op cit, 36-38.

Drummond, op cit, 157-160.

Spurgeon describes that early ministry and its attendant difficulties in Autobiography 1, 219-233.

Kathy Triggs, C.H. Spurgeon: Boy Preacher of the Fens (Basingstoke: Pickering \& Inglis, 1984).
} 
on hard times and only about 200 remained of the congregation. This proved to be a momentous ministry. ${ }^{17}$

Spurgeon was so well received that a few months later, in February 1854, he was invited to go as pastor for a trial period of six months with a view to becoming the pastor of the church. He was reluctant to accept a sixmonth appointment, in case they quickly concluded that they had made a mistake and so he agreed only to a three-month trial. This was unnecessary, however, because the congregation almost immediately realised that this was God's man for them, and Spurgeon in turn settled well and felt a real call from God. On the $28^{\text {th }}$ April he accepted a formal invitation to become pastor and remained in that position until his death thirty eight years later.

His preaching ministry was so blessed by God that soon the building could not accommodate all who wanted to hear him preach the gospel and so it was agreed in August 1854 that an extension should be built to the church. While this was happening the congregation met for several months in Exeter Hall in the Strand which was used mostly for musical concerts. It could hold 4,500 people and was filled to capacity both morning and evening for those months. It is perhaps interesting to note that the largest congregation he ever preached to was on $7^{\text {th }}$ October 1857 when he addressed a congregation of 23,654 in the Crystal Palace, at a national day of fasting and prayer..$^{18}$ And that without any amplification!

On a personal level, we should note that Spurgeon met and married a young woman in the congregation, called Susannah Thompson. ${ }^{19}$ They were married in 1856 and the following year had twin sons, their only children. Unfortunately, Susannah became an invalid at the age of 33 and was seldom able to attend her husband's services after that. Both of their sons became preachers, Thomas succeeding his father as pastor at the Metropolitan Tabernacle, and Charles taking charge of the orphanage.

In the same year as his marriage, Spurgeon began his Pastor's College to train young preachers, but we'll say more about the college and the orphanage later.

Spurgeon was also very involved in the work of the gospel outside his own congregation. He was a friend of Hudson Taylor the great pioneer missionary to China and he often met with George Muller, who (like himself) was involved in a tremendous work among orphans. In addition, he knew people like David Livingstone, and even the Prime Minister, William

\footnotetext{
Murray, op cit, 29-51.

Spurgeon, Autobiography 1, 533.

19 Charles Ray's biography of Susannah is entitled Mrs Spurgeon and is available online: https:// www.biblebb.com/files/SPURGEON/mrsspur.htm
} 
Gladstone who himself was a devout Christian and sometimes came to hear Spurgeon preach. Spurgeon was becoming widely known, and actively involved in various missions and other evangelistic causes. Other famous friends included D.L. Moody, William Booth and Lord Shaftesbury. ${ }^{20}$

He was also much in demand as a preacher beyond his own pulpit. He was always prepared to go and preach elsewhere, sometimes up to ten times a week.

With the kind of numbers of people who wanted to hear Spurgeon preach, even the extension to New Park Street proved inadequate and in May 1856 it was decided to return to Exeter Hall for evening services. This was not very successful. First, because it was some distance from Southwark where New Park Street was, and second because the owners of the Hall were not prepared to give an exclusive let. The congregation began to look for an alternative and eventually settled on the Music Hall in the Royal Surrey Gardens. This building held 10,000 people. The first evening service was held on $19^{\text {th }}$ October. The place was packed to capacity. Suddenly someone shouted 'fire', and the cry was taken up by several people elsewhere in the building. Great confusion ensued which resulted in disaster. Seven people were killed and 28 badly injured. ${ }^{21}$

There seems little doubt that the confusion was started deliberately. There was no fire, and there was no danger. It was a malicious act. You see, Spurgeon was becoming a very well-known figure and had obtained a certain notoriety. There was a jealousy on the part of some who saw the huge numbers attending his services, and there were those who thought him primitive or uneducated. He was constantly attacked in the press, often with wildly inaccurate rumours repeated as fact. He and his family suffered a great deal at the hands of those who opposed him, but he was absolutely convinced both of his calling and of the power of the gospel and so he persisted.

The effects of the tragedy on Spurgeon were very pronounced..$^{22}$ For a time, it seemed as if he might not preach again. In the event, it was the $23^{\text {rd }}$ November before services were resumed in the Music Hall, and then only in the mornings. In the meantime, plans were made for a new building, which was to be called the Metropolitan Tabernacle. A site was obtained in Newington and the foundation stone was laid in August 1859. They had to move out of the Music Hall in December 1859 because the building was

\footnotetext{
20 Nettles, op cit, quotes Shaftesbury as saying of Spurgeon: 'Few men have preached so much, and so well; and few have ever combined so practically their words and their actions.'

21 Shindler, op cit, 94.

22 Spurgeon describes the mpact upon himself of the tragedy in Autobiography 1, 427-451.
} 
needed, and so they had another eighteen months in Exeter Hall before moving into their new building. It was completed in 1861 and was opened on the $18^{\text {th }}$ March.

Congregations remained large. In 1876 there was a census taken of church attendance in London. Those records show that the combined morning and evening attendance at the Metropolitan Tabernacle for one Sunday was 10,000 people. The church had 232 members when he arrived in 1854 and 5,311 by the end of his ministry. The church was the largest independent congregation in the world. On several occasions Spurgeon urged the congregation not to come the following Sunday so that others might get in. Indeed, during one service in 1879 the regular congregation left so that those waiting outside might come in, and the building was immediately filled again!

In addition to this preaching ministry he also had a writing ministry which reached countless thousands. By 1899 over 100 million copies of his sermons were in print in 23 languages. ${ }^{23} \mathrm{He}$ also wrote about 130 books and had his own magazine The Sword and Trowel.

Spurgeon preached for the last time in June 1891. He died seven months later.

\section{Outline}

With that introduction, what I propose to do is to highlight six areas of Spurgeon's life and ministry where I think there are important lessons for us to learn.

\section{His Passion for Souls}

Spurgeon was above all an evangelist. He had a passion for the salvation of men and women which was the driving force in his life. It is said that he preached 600 times before he was 20 ! He was indeed privileged to see many people converted to Christ during his ministry. He once said that by 1856 he had already personally seen 1,000 people who had become Christians.

His passion for souls probably led him to take on too much in the way of preaching engagements outside his own congregation and this, combined with ill health, probably shortened his life. It has been estimated that during his lifetime he preached to around 10 million people.

Even his writing ministry was promoted by his passion for souls. It was simply an extension of his preaching. He wrote in order to reach those

23 A complete set of Surgeon's sermons are available online at: https://www.spurgeongems.org/ spurgeon-sermons/ 
who could not hear him preach. The main thrust of this was the publication of his sermons. By 1865, 25,000 copies of his previous Sunday's sermon sold every week. Several of his books have sold over a million copies. This is to say nothing of the effect of his monthly magazine and the numbers who heard of Christ through reading it. His commitment to the work of Christian literature caused him to form a Colportage Association, and his wife gave her name to a Book Fund to provide Christian books for pastors.

In the spoken word and in the printed word Spurgeon was a man who sought to win souls for his Master. Do we have the same passion for souls?

\section{His Devotion to Prayer and Study}

Spurgeon was a man who was utterly devoted to his Master and to the cause of the gospel. There was an absolute commitment to this great task even when it was difficult. He suffered much opposition, abuse and slander, but he never turned aside from his main task. In short, he always put God before men. This was particularly apparent in two areas of his life: prayer and study.

The emphasis which he placed upon the importance of prayer and prayer meetings is legendary. You will no doubt have heard the famous story of how he was showing a visitor round his church and took him down to see what he called the 'power house' of the church. The visitor, thinking that he was being taken to the boiler room was politely confused until he was shown into a room where hundreds of people were at prayer. That, says Spurgeon, is the powerhouse of the church. He knew that he, Spurgeon, could not build a church. He knew that it could not be built by human means or methods. He knew that only God can build a church, and so prayer is a primary work of any Christian congregation.

He also committed himself to painstaking study in the cause of the gospel. He loved to study the Scriptures and had a particular regard for the great Puritan divines who, he believed, cast more light on the Scriptures than anyone else he had ever read. He routinely read about six books a week, and somehow managed to retain what he read. This helped him because his style of preaching was to have only a few notes and to extemporise.

It must be emphasised, however, that he did not study for study's sake, nor because he simply happened to enjoy it. He studied because he was devoted to his master and in order to prepare himself to be a better preacher. How do we match up to this devotion to the Master? Do we put God before men in everything, always making decisions because we know God's will through the Scriptures rather than trying to please men? Or do we compromise our devotion to the Master by allowing human concerns 
to get in the way of the work of the gospel?

And what about our commitment to prayer? Surely we must agree with Spurgeon that prayer is the powerhouse of the church and that it the duty of every Christian to pray? Surely we must agree that the prayer meeting is where every Christian ought to be? If we believe in a God who is the creator of the whole universe and who answers prayer, we must cry out to him to pour his Spirit out upon us in these difficult days. What about study? Do we study the Scriptures, and do we read Christian books which help us to understand them? Or do we allow other matters to crowd out these vital tasks?

\section{His Attitude to the Bible \& Expository Ministry}

Having spoken of Spurgeon's commitment to the study of the Scriptures we must now emphasise that this commitment stemmed from certain beliefs. In particular he believed that the Bible is the Word of God, breathed out by God, and is used by the Holy Spirit for the salvation of souls and for the upbuilding of Christians.

His attitude to the defence of the Bible is interesting. He said that he would as soon defend a lion! I think what he meant was this: we can spend a great deal of time and energy trying to prove that the Bible is true but in a sense it is far better simply to let the Bible do its work. We could go further and say that we must accept the truth of the Bible as a presupposition in our thinking. If we put the Bible on trial and prove it to be true (to our satisfaction) then in one sense we are doing the same thing as the Liberal theologians. They put it on trial and find it to be full of mistakes, we put it on trial and prove it to be true but both groups are assuming that the human mind is capable of putting God's Word on trial. Spurgeon would have argued that this cannot be. We accept it, and as the Holy Spirit does his work we discover it to be true in all its richness and depth. In this sense, we might regard him as a presuppositionalist before his time!

The Bible was, of course, at the heart and centre of Spurgeon's whole ministry. His method of preaching was expository. In other words, he took a verse or two of the Bible, explained what it meant, and then applied it to those who were listening. That is the purpose of the preacher. If you read the many volumes of Spurgeon's sermons you will see that he does this in a simple and direct way in the language of the people. But his simplicity and his directness should not be misunderstood. There was nothing casual or shallow about his preparation. He buried himself deep in Scripture before preaching. Indeed, he published a little booklet called Commenting 
and Commentaries ${ }^{24}$ in which he displayed a knowledge of biblical commentaries which would terrify many a preacher today. It was his commitment to the Bible which made him want to be sure he had understood its meaning.

So concerned was he for expository preaching that he started his own 'Pastor's College' in $1856 .{ }^{25}$ This college is still continuing today in London and is called 'Spurgeon's College' ${ }^{26}$ It began when a young man with obvious preaching gifts found that his lack of education was holding him back in using these gifts. It developed from there to the point where about 900 men were trained during Spurgeon's lifetime.

There was no educational qualification for entrance, simply evidence of a call to preach the gospel and demonstration of some of the gifts which are necessary for this calling. No-one was barred through lack of finance, money was raised for the purpose; and there was an absolute commitment to Calvinist theology. It provided a training which was probably unique in its day. ${ }^{27}$

What can we learn from this. First, we can learn to share Spurgeon's commitment to the Bible, believing it to be the Word of God. Second, we can encourage and support the work of expository ministry. In Britain in the past 60 years there has developed a growing commitment to expository ministry, stemming from the ministry of Martin Lloyd-Jones in England ${ }^{28}$ and William Still in Scotland. ${ }^{29}$ This has had most encouraging effects on the lives of many churches. Third, we can support the work of theological education. Here in Jakarta you are fortunate to have a faculty committed to God's Word and to educating and training men and women for Christian service. The College deserves your full support.

May I say in passing that the expository ministry which has developed in England and Scotland is in some ways even more significant than that of Spurgeon because it is also systematic. Spurgeon jumped all over the Bible taking a verse from here or there, but the modern expository movement goes through the books of the Bible chapter by chapter, and I would judge that this is better and more in keeping with the way the books of the Bible

\footnotetext{
24 Available on-line at: http://www.romans45.org/spurgeon/misc/c\&c.htm

25 One of Spurgeon's most famous books is his Lectures to my Students (Basingstoke: Marshall Pickering, 1986).

26 https://www.spurgeons.ac.uk

27 Spurgeon was not only committed to educating and training men for ministry, he was also a great supporter and encourager of both theological students and ministers, not least in his writing ministry. For example, C.H. Spurgeon, An All-Round Ministry: Addresses to Ministers and Students (London: Banner of Truth, 1965).

28 Martyn Lloyd-Jones describes his vision for expository ministry in Preaching E Preachers (London: Hodder \& Stoughton, 2013).

29 William Still describes his vision for expository ministry The Work of the Pastor (Fearn: Christian Focus Publications, 2010).
} 
were written.

\section{His Pastoral Ministry}

Spurgeon did not only preach from the pulpit but he ministered to many through his work of individual pastoral care. No one will know how many people he counselled concerning their eternal condition before God. At every opportunity he challenged men and women to accept Christ as their Saviour.

One particular aspect of this pastoral ministry which ought to be noted, was his letter-writing. His was a voluminous correspondence and various collections of these letters have been made. Many of these were collected in an archive by his son, an archive which is now available on-line. ${ }^{30}$ These letters, like the letters of Samuel Rutherford, demonstrate a deep pastoral heart and a love for people. To read them is to be encouraged and to find help. The letters to his own congregation from the south of France when he was recuperating from illness show how much he loved his people and cared for their well-being. ${ }^{31}$

It is when he writes letters dealing with depression that he is seen at his most tender as a pastor and these letters strike a chord with Christians of every era. He was able to write as he did because he himself suffered from depression from time to time. Michael Reeves has explored this in a recent book. ${ }^{32}$ Another author has used Spurgeon's experience to help other Christians deal with depression. ${ }^{33}$

Those in pastoral ministry today will find real help in dealing with the pastoral needs of a congregation by observing Spurgeon's own practice and by reading his letters. In particular, when counselling people with depression, a depth of understanding can be found in Surgeon because of his own experience.

\section{His Practical Christianity}

Spurgeon's Christianity was not only doctrinal, but deeply practical, as indeed true Christianity must always be.

He gave a considerable amount of his time and indeed his money to social care and commitment to the poor and needy in society. He also had strong political views on matters relating to what he would have thought of as practical Christianity, and he made enemies as well as friends by

\footnotetext{
30 http://www.romans45.org/spurgeon/misc/letters.htm

31 Hannah, Wyncoll, The Suffering Letters of C.H. Spurgeon (London: The Wakeman Trust, 2007).

32 Michael Reeves, Spurgeon on the Christian Life (Wheaton: Crossway, 2018) 163-174.

33 Zack Eswine, Spurgeon's Sorrows: Realistic Hope for those who suffer from depression (Fearn: Christian Focus Publications, 2014).
} 
expressing them. From 1867 onwards he was particularly involved in the care of destitute and fatherless children. A Mrs Hillyard had given Spurgeon $£ 20,000$ with which to found an orphanage. The orphanage was built along lines which are more in keeping with the methods and practice of the late $20^{\text {th }}$ century than the late $19^{\text {th }}$. Houses were built where boys could live with houseparents with a number of central buildings. At first it was just boys who were catered for but about 15 years later four houses were built specifically for girls. Spurgeon was very committed to the work of the orphanages, and they held a high place in his priority list, probably second only to the College.

J.G.G. Norman in an article on Spurgeon tells us that he was also instrumental in founding and supporting 'Temperance and Clothing societies, a Pioneer Mission and a Colportage Association'. ${ }^{34}$ We also know that the tabernacle had a large fund for poverty relief and supported Almshouses, Ragged Schools for the poor and other similar enterprises.

What can we learn from this? Perhaps there is really only one lesson here, namely, that faith without works is dead, and that a Christianity which does not lead to a practical, caring way of life is not Christianity at all. That surely is the message of James 2 and Matthew 25?

\section{His Refusal to Compromise on the Truth of the Gospel}

Spurgeon was a man who was valiant for the truth. In this regard he was involved in various controversies over the years. He fought all his life against Arminianism which undermines God's sovereignty and emphasises human responsibility and human freedom. Spurgeon felt that this involved a denial of the grace of God and so he was, and remained, a Calvinist. There were, however, two particular controversies which we ought to mention.

First, the controversy with Anglicans over baptism. On the $5^{\text {th }}$ June 1864, he preached a sermon in which he argued that evangelical Anglicans who baptised any child brought to them, and who used the language of the Prayer Book in their baptismal services were guilty of serious error. The simple meaning of the Prayer Book service, argued Spurgeon, is baptismal regeneration - the view that a baby becomes a Christian at the point of baptism. ${ }^{35}$ He also said something similar about their use of the funeral service in the Prayer Book but it was his remarks on baptism which caused the main stir.

Within a short time 350,000 copies of that sermon were in print and there was an enormous fuss. Spurgeon believed that evangelical Anglicans

34 J.G.G. Norman, 'Spurgeon, Charles Haddon (1834-1892)' in J.D. Douglas (ed) The New International Dictionary of the Christian Church (Grand Rapids: Zondervan, 1974).

35 This incident is described in Autobiography 2, 55-59. 
ought not to associate with those who believed in baptismal regeneration. The Evangelical Alliance was split over this matter, because the evangelical Anglicans who were members were furious at Spurgeon. Eventually he left the Alliance over the issue.

The second controversy in which he was involved was called the 'Downgrade Controversy'. This controversy was even more significant, because it concerned the truth of the gospel. At this time, Liberal Theology and the Higher Critical movement in biblical studies were beginning to have an effect in England. These Critics questioned the authority of the Bible and had begun to ask questions about its historical development and its reliability. ${ }^{36}$

The Liberal theologians wanted to argue that the Reformation and more especially the post-Reformation church replaced an infallible mediaeval Church with an infallible Protestant Bible and that this was unacceptable. For the liberals, the Bible is not an infallible source of truth, but a fallible human book. According to them, we can learn a great deal from the Bible about what Jews and Christians believed at different times in their history but those beliefs and convictions are not binding on us today. We must decide for ourselves what is true and false, good and bad, right and wrong. The Bible is a helpful guide but is not the infallible Word of God.

Most of the impact of this movement was felt on the continent but in 1860 a book was published entitled, Essays \& Reviews. ${ }^{37}$ This was a collection of essays by seven scholars in Oxford, and for the first time the impact of critical scholarship began to be seen in England. A number of the essays challenged orthodox belief and indeed two of the writers were tried for heresy. This proved to be unsuccessful although, as Alistair Heron reminds us in his account of this story, a similar trial took place in Scotland in 1875 when Professor Robertson-Smith was tried for heresy on account of an article he had written in the Encyclopedia Britannica. He was found guilty and deposed from his chair of Old Testament in Aberdeen. ${ }^{38}$

In other words, this was a period when orthodox Christianity was being challenged from within, and was beginning to be damaged by those who would not believe that the Bible was the Word of God.

In the August 1887 edition of The Sword and Trowel Spurgeon addressed himself to the issue of Liberal Theology. He questioned how far evangelicals should share fellowship with these liberals. He followed this up in the

36 For a description of this controversy and its implications see: Nettles, op cit, 541-578; and Murray, op cit, 145-191.

37 (London: John W. Parker and Son, 1860).

38 Alasdair I.C. Heron, A Century of Protestant Theology (London: Lutterworth Press, 1980), 64-65. 
September issue with a statement on the difference between inspiration and speculation. This was written shortly before the Baptist Union was due to meet and Spurgeon had also met with office-bearers from the Union to express his concerns.

At the Baptist Union meeting in Sheffield, however, nothing was done, and so on October $28^{\text {th }} 1887$ Spurgeon left the Baptist Union. As you can imagine this caused an enormous furore. Here was probably the world's most famous Baptist leaving the denominational affiliation! In fact, the Baptist Union, at a later meeting, even passed a motion of censure on Spurgeon, arguing that he had made general charges and not been specific enough and so on. This merely confirmed Spurgeon's view that the members of the Baptist Union were more concerned to keep the peace than to deal with error and heresy. The controversy went on for some time, and the details don't concern us here but it certainly was a crucial period in Spurgeon's ministry.

What lessons, then, can be learned from these controversies, which will help us today? I think it is best expressed by saying that our commitment to truth must be paramount. The voice of God, speaking by his Spirit through the Scriptures is our final authority in all decision-making and in all issues of belief and practice. Spurgeon felt the need to leave both the Evangelical Alliance and the Baptist Union. Others who were equally concerned felt the need to stay in these organisations and fight for what they believed. Either way, the most significant matter is the fight for truth. Spurgeon felt that in both cases fellowship or peace had been put before truth, and this he regarded as a pathway to disaster.

\section{Conclusion}

Spurgeon died 128 years ago but the gospel he preached and the theology he believed are still as relevant as ever. Not only so, but his devotion to his Master and his great desire for the salvation of souls, coupled with a commitment to the Scriptures and prayer, make him a preacher well worthy of study. This is to say nothing of the fact that his commitment to biblical Christianity showed itself just as much in the cause of the poor and needy as in his determination to stand for the truth against the liberal theologians of his day.

Undoubtedly there is a great deal about Spurgeon and his ministry which could usefully be re-learned by evangelicals today, both for the furtherance of the gospel and for the strengthening of evangelical theology. 